\title{
Hunting and Fishing Focus Among the Miskito Indians, Eastern Nicaragua
}

\author{
Bernard Nietschmann ${ }^{1}$
}

Received April 30, 1971; revised November 17, 1971

The amounts of native animals taken in hunting and fishing by Amerind peoples are almost unknown. The interrelationships of cultural and ecological systems determine to a large extent hunting and fishing returns, focus, and strategies. This study presents data obtained in a coastal Miskito Indian village in eastern Nicaragua. Measurements were made of meat yields by species and of the time and distance inputs involved in securing fish and game. Hunting and fishing focus and strategies are adaptive mechanisms enabling the Miskito to achieve high and dependable returns from a limited number of species. Several factors are examined which influence hunting and fishing focus: dietary preferences and prohibitions, costs involved, differential productivity and dependability of particular species, seasonality and scheduling, and the impact of cash market opportunities for faunal resources. Under the impetus of population growth and rising aspirations, the Miskito's efforts to secure increasing numbers of animals for both subsistence and market are leading to severe pressures on selected species and to cultural and ecological disruptions.

\section{INTRODUCTION}

Hunters do not range randomly through their environments in search of game. Nor do fishermen move aimlessly across stretches of water seeking undifferentiated fish. Hunting and fishing efforts are usually highly focused on specific animals, in specific locales, and at specific times of the year. For many Indian groups in Latin America, hunting and fishing are not undertaken on a basis of "catch as catch can" or "anything that moves goes into the pot." There is a range of hunting and fishing focus on local faunas depending on cultural

This study is part of a larger project on Miskito subsistence ecology carried out in 1968-1969 with a grant from the Foreign Area Fellowship Program. Additional data were obtained May through August 1971, supported by a Social Science Research Council grant.

1 Department of Geography, Univer sity of Michigan, Ann Arbor, Michigan. 
preferences, ethnozoological classifications, and the dependability, availability, and productiveness of particular species. Increasingly, the selection of animals is being determined by economic factors, such as foreign markets for animal skins and regional and local sale of meat. Lack of attention by investigators to the importance, diversity, and concentration of hunting and fishing has often served to confuse and mislead attempts at an understanding of Amerind ecology, subsistence, adaptation, carrying capacity, and their impact on the environment.

Hunting and fishing still play an important role in subsistence in Latin America. In addition to the numerous groups of lowland tropical Amerinds in South America, there are various indigenous peoples in Middle America who still depend on hunting and fishing as their major source of animal protein. Many peasant groups also get at least some of their food from hunting and fishing.

The availability and dependability of securing animal protein through hunting and fishing are important influences on settlement and adaptation for many Amerinds in tropical Latin America. Carneiro $(1960,1961,1964)$ has shown that most tropical forest agricultural systems are capable of producing vegetable food far in surplus of what is needed by existing populations. It may not be the agricultural potential nor the size of the area available for agriculture which alone influence population size and location, and the area's carrying capacity, but other factors such as protein-rich fish and game resources. Denevan (1966), Lathrap (1968), and Carneiro (1970) have all commented on the possible importance of protein obtained from hunting and fishing in terms of population distribution and settlement location, especially for people whose crop staples are roots and tubers and who have few or no domesticated animals.

Despite the suspected importance of native animals in Amerind diets, their possible effect on human carrying capacity and settlement location, and the growing list of overexploited endangered species, we know almost nothing about the amounts and types of fish and game animals taken by a specific group over a period of time. In reviewing ecological research in Middle America, Bennett (1967: 18) noted that "we have only vague ideas about the quantitative aspects of hunting and fishing success under different environmental and technological conditions." Few published studies exist for any one group where hunting and fishing yields were measured. ${ }^{2}$ Bennett (1970: 25-26) later remarked:

The exploitation of the wild animal resource base as a food source by Amerinds has received inadequate attention from scholars who have studied Amerind societies. Too often a list

2 In his study of diet and livelihood of the Bayano Cuna Indians of Panama, Bennett (1962) presented virtually the only available detailed information on hunting and fishing catches based on 14 days of recorded species, numbers, and weights. 
of animals said to be eaten by the group under investigation is felt to supply all needed information.... One is generally told nothing about quantities taken of a given species, seasonal aspects of hunting and fishing, the nutritional contribution made by this dietary input (we know there are fats and proteins but how much and what percentage of the total intake is accounted for by this source?)...

In short, we know very little about the actual significance, effectiveness, and rationale of hunting and fishing by a particular Amerind group, and what impact any of these have on settlement and subsistence, or on the wild animal populations themselves and their ecosystems.

Based on our research, I would like to argue that hunting and fishing activities are often very productive, are not carried out "helterskelter," and are very responsive to internal and external economic fluctuations and changes, which may, in turn, be leading some groups to intensify and concentrate their efforts causing ecological and cultural disruptions.

During our first field research with the Miskito Indians of eastern Nicaragua, daily subsistence activities and returns were measured for one year in a village located on the Caribbean Coast. It soon became evident that Miskito hunting and fishing activities were directed toward very specific animals out of a wide variety of seemingly available species and that efforts were focused on the shallow offshore waters rather than the adjacent tropical rain forest. Even though the village was situated favorably for ready access to both environments, $65 \%$ of the men concentrated solely on turtle fishing, $20 \%$ on both hunting and fishing, with but $15 \%$ devoting all their attention to hunting.

In order to answer why this Miskito village was so focused on species, site, and occupation, we based our analysis on measured meat yields from hunting and fishing, ${ }^{3}$ time and distance inputs, productivity and dependability, economic costs and returns, Miskito attitudes and preferences for meat, and behavioral characteristics of the animal populations. The second major question to be raised in this paper is what effects do focused hunting and fishing patterns have on the Miskito and on wild fauna populations?

\section{THE MISKITO AND THE MISKITO COAST}

\section{The Miskito}

The Miskito Indians are the dominant cultural group in eastern Nicaragua,

3 Daily records were kept for one year from October 1968 through September 1969 of game meat and fish brought into the village by hunters and fishermen. The animals were weighed before and after butchering. The location where the animal was taken was also recorded, as well as the distance and time involved. Time and distance yields provided a core of measurable data, along with dietary samples. 
and they are the second most widely distributed Indian people in Central America, after the Maya. The Miskito are a water-side people and settlements are almost always located along a river, lagoon, or coastal beach. The Miskito are scattered along 400 miles of Caribbean Coast from Cabo Camarón in Honduras to the southern end of Pearl Lagoon in Nicaragua, and almost 400 miles up the Río Coco. Their present-day population in Nicaragua is approximately 35,000 , the majority divided between coastal villages $(10,000$ to 15,000 total population) and Río Coco riverine villages (14,000 to 15,000 total population) (Nietschmann, 1969: 94). The study village of Tasbapauni with a population of 997 is one of the largest Miskito settlements (see Figs. 1a and 1b).

The Miskito were one of the many aboriginal groups which inhabited the east coast of Nicaragua whose cultures and languages were derived principally from lowland tropical South America (Adams, 1956: 897-899; Kirchhoff, 1948). At first European contact in the early seventeenth century, the Miskito numbered no more than 2000 and were centered on the northeast coast of Nicaragua at Sandy Bay and Old Cape. Their emergence as the major native group in Nicaragua and their diffusion into very different environments have come about since European contact, principally through territory and population gained by warfare with neighboring Sumu Indians.

The subsistence system of the Miskito is based on slash-and-burn agriculture (manioc, bananas, plantain, Xanthosoma) and hunting and fishing. Small purchases are made of flour, sugar, salt, beans, coffee, and other items which the Miskito now feel are a necessary part of life.'

In order to obtain money the Miskito today are turning to their local

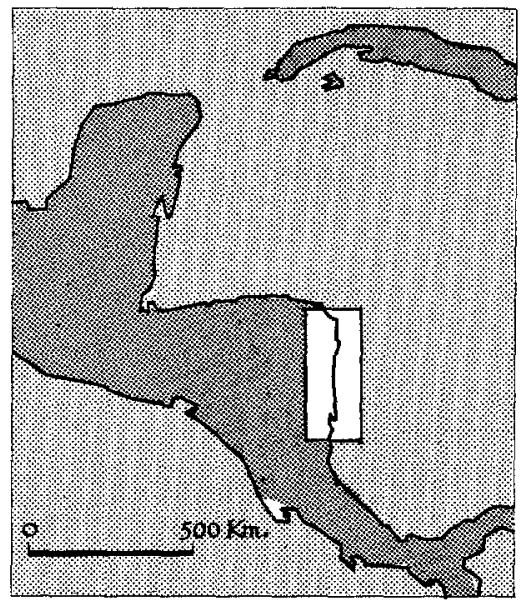

Fig. 1a. Nicaraguan coastal Miskito settlements shown in relation to the rest of Nicaragua and Central America. 


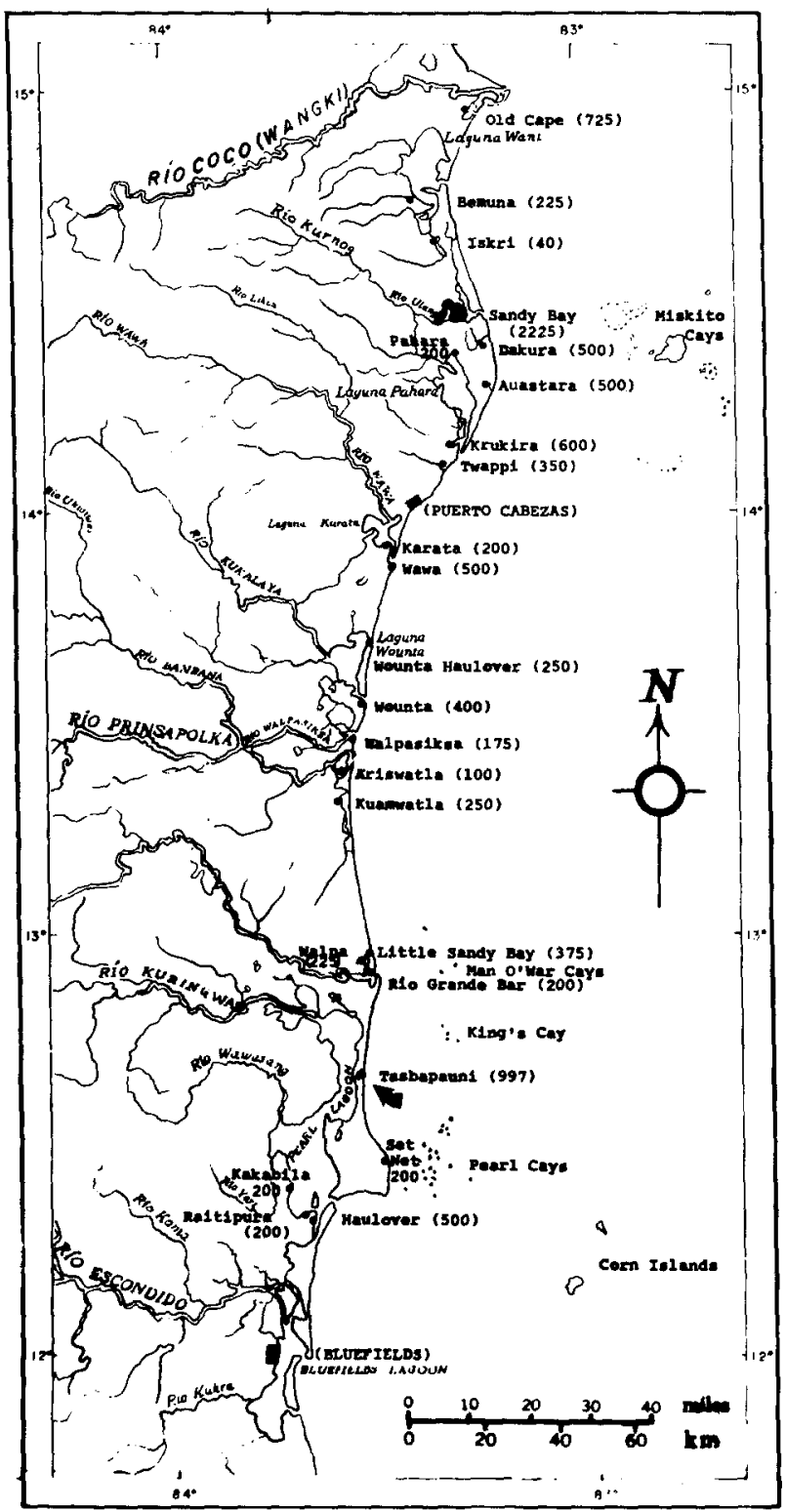

Fig. 1b. Detailed map of coastal Miskito settlements, showing the village of Tasbapauni. Figures in parentheses indicate approximate population. 


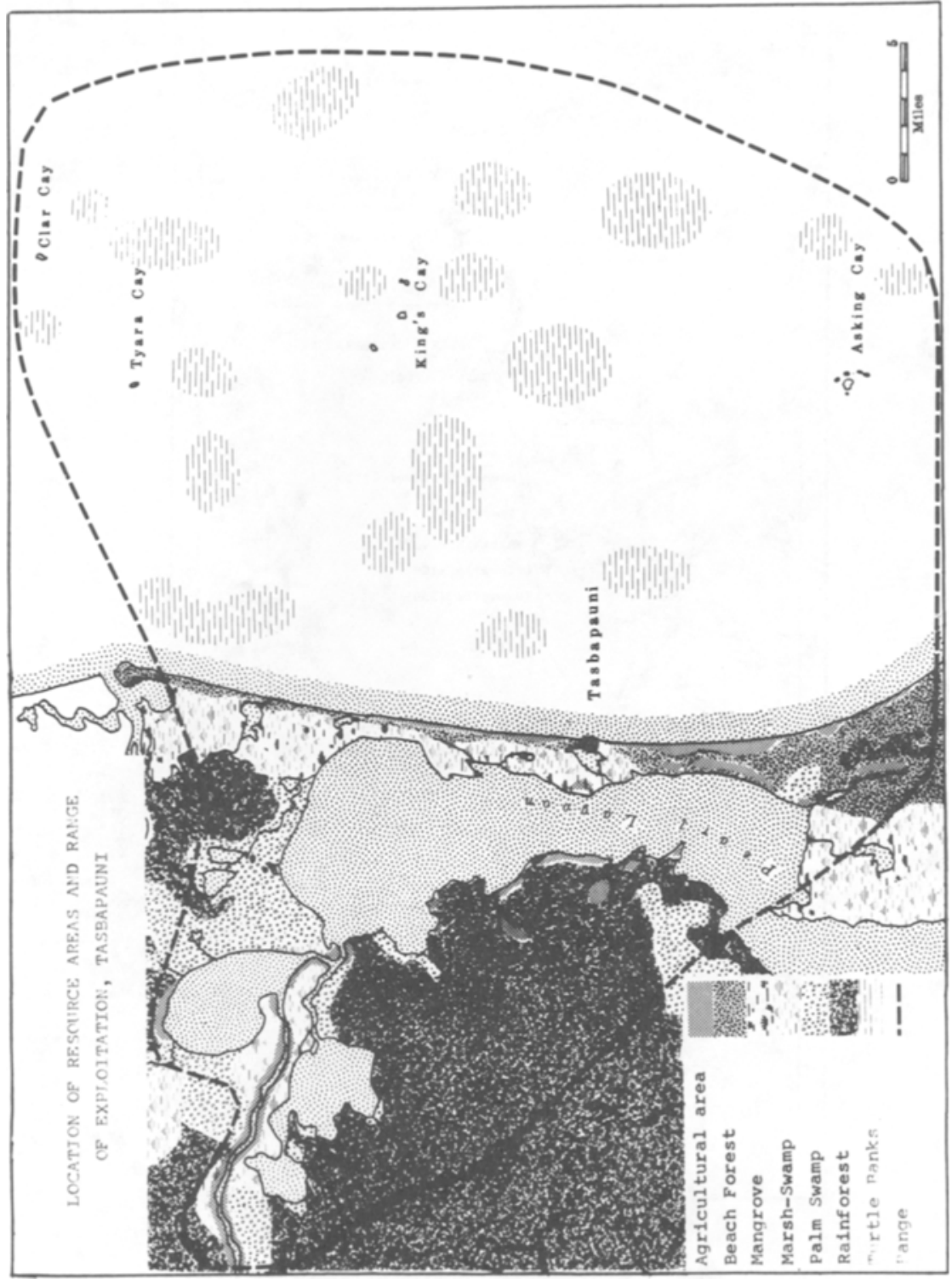

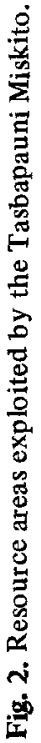


environments to extract products which can be sold or traded for the desired goods. The market economy of the coastal Miskito is based on green turtles (Chelonia mydas), hawksbill turtles (Eretmochelys imbricata), coconuts, jaguar and ocelot skins, shrimp, and small amounts of agricultural crops, principally rice, bananas, and plantains. Domesticated animals are scarce, and the few that are raised are usually sold to visiting outside buyers.

\section{Village and Environment}

The study village of Tasbapauni lies on a narrow stretch of beach separating Pearl Lagoon from the sea and is approximately 40 miles north of Bluefields, the major town on the coast. The Tasbapauni area is a complex of varied environments with different associations of fauna and flora offering numerous combinations of hunting and fishing opportunities in terms of species, site, and season (Fig. 2). To the west of the village, across the lagoon, are large expanses of tropical rain forest, scattered palm swamps, and gallery forests inhabited by a diverse coastal fauna. An extensive marine shelf extends far out into the Caribbean Sea off Tasbapauni. The marine fauna of the shallow offshore waters correspond to most species found throughout Caribbean waters. This area has the largest sea turtle feeding grounds in the Western Hemisphere (Carr, 1967: 98), dominated by Zostera and Thalassia turtle grasses. The green turtle (Chelonia mydas mydas) is a major source of meat for the coastal Miskito and the basis of much of their livelihood. Turtling activities are concentrated on the feeding grounds ("turtle banks") and shoal areas located 5 to 28 miles from Tasbapauni.

The land-water zone within the range of exploitation of Tasbapauni hunters and fishermen totals 850 square miles, which includes 625 square miles of ocean, 125 square miles of lagoons, rivers, and creeks, and 100 square miles of land. Not all of this area receives the same intensity of exploitation, of course. The 850 square miles include all of the territory which is visited or traversed during the year for food-getting.

The village of Tasbapauni receives approximately 160 inches of precipitation annually. A period of relative dryness occurs from February to mid-May and at the end of September. These months are characterized by much reduced precipitation totals, generally under 5 inches, long periods of hot, rainless days, often 10 to 15 days or more, and short rainfalls, lasting only a few hours. Heavy rains fall between June and August, with July usually recording over 30 inches. The rest of the year is generally wet, most months receiving at least 10 inches in the Tasbapauni area.

Associated with changes in seasonal precipitation patterns are shifts in

wind and current directions and intensities. During months of heavy rainfall, river discharge is tremendously increased and vast areas of the coastal lowlands 
Table I. Average Live and Butchered Weights (in Pounds) of Important Game Animals, Tasbapauni

\begin{tabular}{lrr}
\hline & $\begin{array}{c}\text { Butchered } \\
\text { weight (lb) }\end{array}$ & $\begin{array}{c}\text { Live } \\
\text { weight (lb) }\end{array}$ \\
\hline Tapir (Tapirella sp.) & 250 & 525 \\
Manatee (Trichechus manatus) & $200^{a}$ & 500 \\
Green turtle (Chelonia mydas) & $90-100$ & $190-210$ \\
Whitetail deer (Odocoileus virginiana) & $60-65$ & $85-90$ \\
White-lipped peccary (Tayassu pecari) & 50 & $73^{b}$ \\
Hawksbill turtle (Eretmochelys imbricata) & $40-50$ & 105 \\
Brocket deer (Mazama americana) & 40 & $60^{b}$ \\
Collared peccary (Pecari tajacu) & 40 & $55^{b}$ \\
Paca (Cuniculus paca) & 15 & 21 \\
Spider monkey (Ateles geoffroyi) & 12 & 20 \\
Armadillo (Dasypus novemcinctus) & 7 & 13 \\
Agouti (Dasyprocta punctata) & 6 & 9 \\
Iguana (Iguana sp.) & 6 & 10 \\
White-face monkey (Cebus capucinus) & 5 & 8 \\
Hicatee fresh-water turtle (Pseudemys sp.) & 5 & 15 \\
\hline$a$ Plus oil made from fat. & & \\
S Said to be large. & & \\
$c_{\text {Including immature eggs. }}^{c}$ & &
\end{tabular}

are flooded, and coastal longshore currents are widened and accelerated. All of these alterations in wind and water patterns greatly influence Miskito hunting and fishing efforts since transport is largely by dugout sailing canoes. In addition, fish and game populations are rearranged in location and densities due to flooding, or, in the case of aquatic species, because of salinity, turbidity, and temperature fluctuations, as well as currents.

Table II. Pounds of Butchered Fish, Game, and Domesticated Animals Consumed in Tasbapauni, October 1968 Through September 1969

\begin{tabular}{lcr}
\hline & Percent & Pounds \\
\hline Green turtle & 70 & 76,860 \\
White-lipped peccary & 7 & 7,245 \\
Fish & 6 & 7,100 \\
Whitetail deer & 5 & 5,800 \\
Shrimp & 3 & 3,870 \\
Collared peccary, brocket deer, iguana, & & \\
$\quad$ manatee, tapir, paca, agouti, monkeys & 3 & \\
$\quad$ armadillo, birds, shellfish, coati & 2 & 2,800 \\
Pigs, goats, cattle, fowl & 2 & 2,490 \\
Hicatee turtle & 2 & 2,380 \\
Hawksbill turtle & 100 & \\
$\quad$ & & 110,050 \\
Total & & \\
\hline
\end{tabular}




\section{HUNTING AND FISHING}

Hunting and fishing activities form the core of village life. Meat is the single most sought after food and is the center of interest in the village. Deprived of meat, many women refuse to cook; or they are indifferent about it at best. As one Miskito man explained it:

You've got to have meat to eat. Without meat many people don't make a fire from morning until evening. They get hungry. If you're lucky and you get meat, all of those kitchen fires burn to cook that meat. And people are happy.

Out of approximately 160 men between the ages of 21 and 60 in the village, 124 did some hunting and fishing during the 1968-1969 period of field research. ${ }^{4}$ Of these, 80 turtled (65\%), 26 hunted and turtled (20\%), and 18 hunted $(15 \%)$. The reasons that only $20 \%$ of the adult males in Tasbapauni exploit both land and water environments, while $80 \%$ of the men concentrate on only one or the other, can be explained to some extent by the prohibitive costs of owning two sets of different equipment. Few can master, as well as afford, the varied technology and necessary skills to be successful in all phases of hunting and fishing, at all times of the year, and with equal proficiency for land and water. But there are other reasons as well.

\section{Fish and Game Animals}

The most common game animals and their average live and butchered weights are listed in Table I. The butchered weights represent "clean meat" portions after the animal has been gutted, cut up, and most of the nonedible parts removed. Bones were included in butchered weights as they are not removed for the sale of meat or for cooking.

The approximate amount of meat consumed in Tasbapauni during a 12-month period is presented in Table II. Almost the entire total (92\%) was obtained by hunting and fishing. These totals do not include shrimp and green turtles sold outside the village, animals used to bait deadfall traps (used to catch jaguars and ocelots), nor spotted cats and river otters taken for skins. ${ }^{5}$ Of the total $110,600 \mathrm{lb}$ of meat, $6244(5 \%)$ were obtained by trade or purchase from outside the village; domesticated animals butchered in Tasbapauni contributed 2490 (2\%); 101,866 lb came from hunting and fishing efforts of the men of Tasbapauni.

4 The remaining 36 men did no hunting and fishing because they either were sick, were disabled, had a sustaining specialty craft or occupation (building sea-going dugout canoes, owning diesel boats, repairing boats), or simply did not like the rigors of hunting and turtle fishing. They were usually able to obtain meat by purchase or through kin.

Approximately $40,000 \mathrm{lb}$. of fresh shrimp and 82 green turtles were sold. These totals are not included in Table II. 


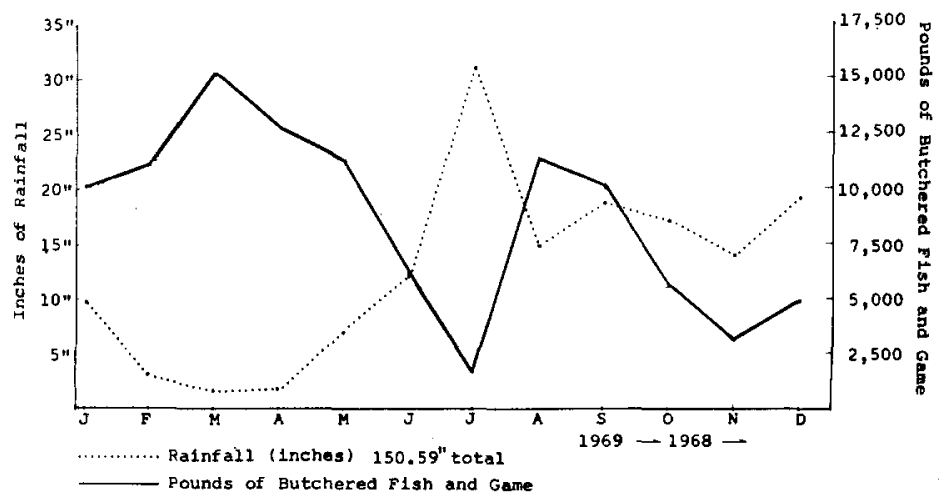

Fig. 3. Seasonality of meat yields from hunting and fishing, Tasbapauni, 1968-1969. Monthly totals of butchered fish and game (in pounds) and rainfall totals (in inches) are shown. Amounts of rainfall also reflect the strength and intensity of currents and winds.

Meat yields by environment from hunting and fishing are as follows: (1) $75 \%$ from inshore and offshore marine waters, (2) 15\% from tropical forests, palm swamps, and swidden sites, and (3) $8 \%$ from fresh-water lagoons, rivers, and creeks. The percentages of meat returns from each area correspond closely to the percentages of men engaged in different meat-getting activities.

The most important animals in terms of total weight and number of animals killed (Table III) are green turtle, white-lipped peccary, fish, and whitetail deer. The high percentage of green turtles in the Tasbapauni diet indicates how important this animal is to the villagers. The coastal Miskito have adapted much of their technology, lifeways, and internal and external economic patterns to the predictable behavior patterns and relatively dependable catches of green turtles. By focusing on the green turtle a great deal of pressure has been taken off terrestrial animal populations which under other conditions would

Table III. Number of Most Important Animals Taken by Tasbapauni Hunters and Turtlemen for One Year, October 1968 Through September 1969

\begin{tabular}{lr}
\hline Green turtle & 819 \\
White-lipped peccary & 133 \\
Whitetail deer & 95 \\
Hawksbill turtle & 41 \\
Hicatee fresh-water turtle & 434 \\
Iguana & 40 \\
Collared peccary & 2 \\
Tapir & 1 \\
Manatee & 1 \\
Brocket deer & 1 \\
\hline
\end{tabular}


receive more hunting attention. Along the Río Coco, in contrast to Tasbapauni, there is less game meat in the diet, and river fishing is the dominant source of animal protein.

\section{Seasonality of Meat Yields}

Fish and game animals are not consistently available in number, place, or season. Both the types and amounts of meat taken in hunting and fishing fluctuate throughout the year. A close relationship exists between changes in weather and sea conditions, local and extra-regional faunal movement, and the variability of meat yields. The line indicating monthly rainfall totals in Fig. 3 also reflects other environmental changes. Periods of heavy or light rainfall are accompanied by differences in the velocity of offshore currents, changes in wind directions and intensities, and rearrangements of fish and game populations, most markedly the movement of green turtles. Equally as important as the environmental and biological processes affecting the availability and accessibility of fish and game resources is whether or not they are "in phase" with work demands in other spheres of the subsistence system. Thus, the February to May dry season, when green turtles are the most plentiful and easily caught, is the period when agricultural work (clearing, burning, planting) has to be done.

Much of the seasonality of meat supplies revolves around green turtle migration patterns. ${ }^{6}$ Starting in April, the first group of adult turtles leaves for the Tortuguero, Costa Rica, nesting beach. Turtles continue to leave the feeding grounds May through early June. From June to the first part of August turtling activities also diminish because of adverse weather conditions, primarily strong currents and winds. The turtles begin to return from nesting in late July and continue arriving until most are back by September. During their absence meat yields drop off greatly and are only partly ameliorated by hunting returns.

The greatest amount of hunting takes place during the high rainfall months from June to August due to meat shortages in the village and the ease with which flood-trapped animal populations can be killed along riverbanks and on low hills in swamps. For example, during the extremely high flood of July 1971 , 55 whitetail deer (Odocoileus virginiana) were killed by hunters from Tasbapauni. In general, hunting is carried on throughout the year in swamps, gallery forests, and swidden sites for deer, and in the tropical rain forest for white-lipped peccary (Tayassu pecari).

Meat consumed in the village reaches its highest volume during the dry-season months of February, March, and April when weather and turtling

6 Detailed descriptions of green turtle long-distance migration behavior are given by Carr (1967) and Parsons (1962). An historical account of Miskito green turtle fishing is also included in the Parsons study. 


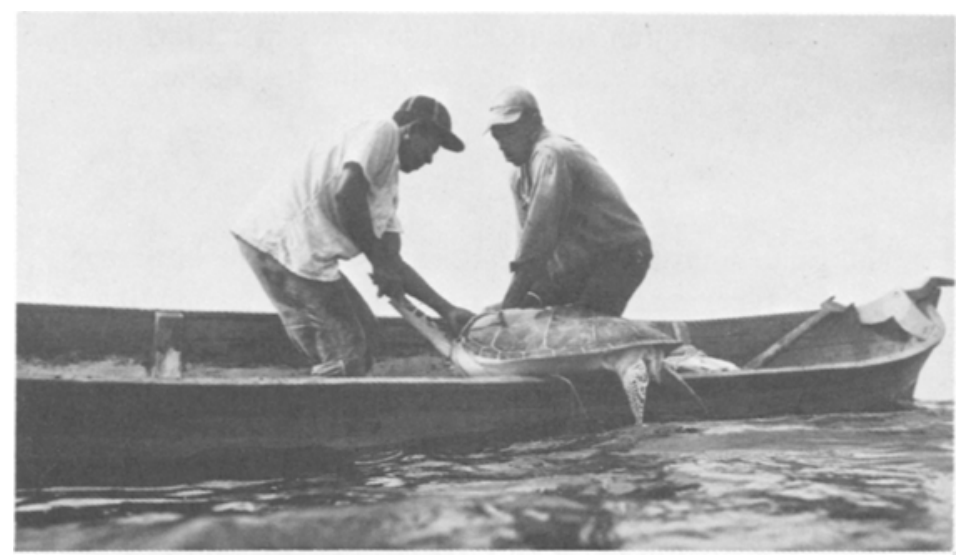

Fig. 4. After a $1 / 2$ hour fight, this exhausted medium-size green turtle is being hauled on board by Tasbapauni turtlemen. The detachable harpoon point can be seen stuck in the turtle's shell. (On the turtle banks east of Tasbapauni, 1969.)

conditions are optimal. A drastic difference in meat totals occurs in mid-May and intensifies through June, July, and August as the turtles migrate southward and the rains and stiff winds and currents begin. Meat returns increase in the latter part of August and September during the short dry period. From September to the end of November, total monthly amounts of meat in Tasbapauni decrease as a result of labor demands for the rice harvest, contrary winds in October, and strong north winds in November. The absence of a morning land breeze, strong littoral flood currents, and contrary winds often prevent the Miskito from going to sea in search of turtles.

The variability of meat yields points out one of the most important ecological relationships between the Miskito and their environment, that of the interaction of weather and sea conditions, turtle migration patterns, and the amphibian life of the turtlemen. The timing and success of turtling is largely dependent on these two major environmental factors. Turtlemen act as the adjustive link between the village's desire for meat and the vagaries and certainties of the sea and turtles (Fig. 4).

\section{Contribution of Hunting and Fishing to Diet}

Of the diets sampled in Tasbapauni ${ }^{7}$ the average daily caloric intake for an

7. Intensive dietary measurement was done during two 14-day periods (one in May and the other in July 1969) and intermittently at other times of the year for three sample families. 
Table IV. Estimated Daily Consumption of Calories and Protein for Individuals and for Tasbapauni, October 1968 Through September 1969

\begin{tabular}{|c|c|c|c|c|c|c|c|}
\hline & \multicolumn{3}{|c|}{ Individual } & \multicolumn{4}{|c|}{ Tasbapauni } \\
\hline & $\begin{array}{l}\text { Cal- } \\
\text { ories }\end{array}$ & $\begin{array}{l}\text { Animal } \\
\text { protein } \\
(\mathrm{g})\end{array}$ & $\begin{array}{l}\text { Vege- } \\
\text { table } \\
\text { protein } \\
(\mathrm{g})\end{array}$ & $\begin{array}{l}\text { No. of } \\
\text { indi- } \\
\text { viduals }\end{array}$ & $\begin{array}{l}\text { Cal- } \\
\text { ories }\end{array}$ & $\begin{array}{l}\text { Animal } \\
\text { protein } \\
\text { (g) }\end{array}$ & $\begin{array}{l}\text { Vege- } \\
\text { table } \\
\text { protein } \\
\text { (g) }\end{array}$ \\
\hline Adult male & 2500 & 30.0 & 23.2 & 178 & 445,000 & 5340 & 4130 \\
\hline Adult female & 2200 & 26.4 & 20.9 & 165 & 363,000 & 4356 & 3449 \\
\hline $\begin{array}{l}\text { Adolescent } \\
\text { males }\end{array}$ & 2000 & 24.0 & 18.6 & 112 & 224,000 & 2688 & 2083 \\
\hline Adolescent & 1900 & & 176 & 143 & 271700 & 3260 & 2517 \\
\hline Children 6-10 & 1250 & $\begin{array}{l}22.0 \\
15.0\end{array}$ & $\begin{array}{l}17.0 \\
11.6\end{array}$ & $\begin{array}{l}143 \\
183\end{array}$ & 228,750 & $\begin{array}{l}3200 \\
2745\end{array}$ & 2123 \\
\hline Children 2-5 & 1000 & 10.0 & 11.3 & 150 & 150,000 & 1500 & 1695 \\
\hline Children 1 year & 800 & $?$ & 7.0 & 35 & 28,000 & - & 245 \\
\hline $\begin{array}{l}\text { Children less } \\
\text { than } 1 \text { year }\end{array}$ & $?$ & - & - & 31 & $?$ & $?$ & $?$ \\
\hline Total & & & & 997 & $1,710,450$ & 19,889 & 16,242 . \\
\hline
\end{tabular}

adult male ranged from 2000 in July, when all foods were scarce, to 2400 in May, when crops were scarce and turtle abundant, to 2800 in September, when the first manioc crop was ready and green turtles returned from nesting. The daily average for a one-year period was approximately 2500 calories. Caloric intake was extremely variable; some days a man would barely consume 1000 calories. When food became plentiful, daily consumption levels often rose to 4000 or 5000 calories. The present percentages of calories secured by the Tasbapauni Miskito by different means of food procurement roughly are: agriculture $74 \%$, purchased store foods $18 \%$, hunting and fishing $7 \%$, and gathering $1 \%$.

Protein returns from hunting and fishing are fairly high, and the amount of daily protein intake averages 50 to 60 grams (g) (mostly of animal origin). Large amounts of essential amino acids are supplied in animal organs and muscle tissues, and the Miskito's consumption of almost all parts of an animal greatly improves the utilization of the intake of proteins.

The approximate daily consumption of calories and protein for men, women, children, and for the village of Tasbapauni is shown in Table IV. These figures were derived from three sample families, extrapolating for the village 
totals. Based on these data an average family of seven, including an adult man and woman, adolescent girl and boy, one child six to ten years old, and two children two to five years old, would consume approximately 12,000 calories per day (about 4,380,000 per year) and $138 \mathrm{~g}$ of animal protein or about $1 \frac{112}{\mathrm{lb}}$ of meat per day ( $548 \mathrm{lb}$ per year). Average daily consumption rates for the village of 997 people work out to $19,889 \mathrm{~g}$ of animal protein (roughly $220 \mathrm{lb}$ of meat). In other words, the current rate of meat consumption can be satisfied with two medium-sized green turtles per day, assuming a theoretically even distribution of meat. However, since meat is not distributed equally and since Miskito meat appetites are large, cultural satisfaction would require five or six turtles to be butchered every day. In explaining the difficulties of securing enough meat for kin and fellow villagers, one Miskito turtleman told me: "Everyone can't get meat because there is not enough meat. That's what the problem is. Some have to get meat; some are not going to get meat. That's the way it is."

\section{REASONS FOR HUNTING AND FISHING FOCUS}

It is apparent then that most of the meat from hunting and fishing comes from three species (green turtle, white-lipped peccary, and whitetail deer) almost to the exclusion of other species. Hunting and fishing meat yields correspond to hunting and fishing focus, so that most of the Miskito's search time is spent on very few animals. Thus Miskito hunting and fishing efforts are concentrated on large animals in localized areas and on small animals having high population densities. Most of the meat-getting activites are oriented toward the sea and to green turtles. Fluctuations in animal population location and weather and sea conditions necessitate hunting and fishing strategies which will maximize return by playing off meat-getting efforts among land and water, species, and season. It remains to examine some of the possible reasons, implications, and consequences which are involved in Miskito hunting and fishing focus and strategies.

\section{Preference and Prohibition}

Many animals are considered culturally unavailable for food ${ }^{8}$ and others are accessible for limited periods only and, even then, occur in diverse places. The most esteemed fish and game animals in Tasbapauni include green turtle,

8 These include, for example, trunkback (Dermochelys sp.) and loggerhead (Caretta sp.) turtles, many fish, and howler monkeys (Alouatta). Food restrictions also ex ist for the hawksbill turtle (Eretmochelys imbricata), collared peccary (Pecari tajacu), shrimp (Penaeus), jack fish (Caranx), tarpon (Megalops atlanticus), and lobster (Panulirus argus) among others. 
white-lipped peccary (Tayassu pecari), whitetail deer (Odocoileus virginiana), hicatee fresh-water turtle (Pseudemys sp.), manatee (Trichechus manatus), and fish of many kinds, but principally catfish (Arius melanopus, Bagre marinus), mojarra (Cichlasoma sp.), stingray (various genera), and coppermouth (Cynoscion sp.). Dietary preference of specific fish and game animals determines to a large degree the intensity and frequency of exploitation efforts.

The Miskito do not consider all animal flesh as belonging to the same generic classification, "meat." A subtle distinction is made between animals which are regarded as having meat and lesser animals which have only "flesh" or second-quality meat. The most esteemed animals mentioned above fall into the class of "real meat," while animals such as the following are believed to have inferior flesh: agouti (Dasyprocta punctata), armadillo (Dasypus sp.), coatimundi (Nasua narica), iguana (Iguana sp.), white-face monkey (Cebus capucinus), and various birds and some shellfish.

Since meat is considered the most important food, necessary for the quality of Miskito life, and can only be obtained from specific animals, the focus of hunting and fishing is concentrated on these animals. Futhermore, the most common way to express and to fulfill kinship ties and obligations is through the generalized reciprocity of meat. One could not honor meat-giving responsibilities with a piece of inferior or second-class meat.

The size of the animal is also important in meat exchange relationships. If the animal is small, as are most of the "inferior meat" animals, then it usually goes into the family's cooking pot, no questions asked. However, if a hunter or turtleman brings a large animal into the village, it is believed to be a conspicuous display of wealth and well-being. All that meat! It must be shared, for clearly there is enough for many.

Both increased social prestige and "futures" on the meat exchange are obtained through meat-giving in quantity. And quantity is most of ten acquired by killing large animals.

\section{The High Cost of Hunting and Fishing}

Just as the Tasbapauni Miskito's environment is made up of different places with various fauna, so too are their hunting and fishing methods composed of analogous sets of different technologies, strategies, labor arrangements, and sea and forest knowledge. Fishing alone involves a complex set of radically different technologies and strategies for turtle, manatee, shrimp, and different fish. The major piece of equipment needed for turtling and for journeying to hunting grounds is a dugout canoe (dori in Miskito) fitted for sailing. Most hunting is done with .22 rifles and 12-and 16-gauge shotguns. Fish are taken with a variety of lances, harpoons, and nets. Turtles are usually harpooned; some are taken with nylon turtle nets during the February to May and September "dry season" when the sea is calm. 
Hunting and fishing equipment expenses are high. A good sea-going dugout canoe costs from $\$ 50.00$ to $\$ 100.00$ to build, depending on the amount of expenditures for hired help and materials. A canoe is needed for both hunting and fishing and most men have one or form partnerships with someone who has a canoe. A .22 rifle costs $\$ 50.00$, a shotgun $\$ 40.00$ to $\$ 100.00$. Similarly, turtle fishing is expensive. Besides the canoe, costs involve files to make harpoon points and nylon or cotton lines. One turtle net costs $\$ 7.00$ if made from nylon line, and a man who "sets nets" usually has 10 to 25 nets.

Therefore the $20 \%$ of the adult males in the village who both regularly hunt and take sea turtles have not only mastered the skill and knowledge to operate in land and water environments, but probably more importantly they have the two sets of equipment to do so. For the majority of the men, however, economic constraints limit involvement in two meat-getting systems.

When hunting, the Miskito concentrate on white-lipped peccary, not only for its highly esteemed fatty meat but because these animals travel in large droves of 100 to 200 individuals. If attacked, the droves display a "covered wagon" defense which allows a hunter to be reasonably successful if armed with a shotgun and sufficient shells. Hunters are increasingly feeling the need to have a shotgun so that they can make large kills.

One of the factors which is locking the Miskito into a narrower range of hunting and fishing is economic cost and return. High outputs for guns, shells, lines, and rigging necessitate return in kind and quantity. One hunts and fishes for animals which can also be sold in order to acquire money to maintain hunting and fishing. This leads to a narrow spectrum of perceived possibilities, concentration on few species, and a restricted but intense tap on ecosystem energy sources.

\section{Hunting and Fishing Productivity}

Returns from hunting and fishing can be measured according to dependability and productivity. That is, how often does one have to go out to sea or into the rain forest and how much time does it take to find, kill, and return with an animal.

Productivity relationships are important indicators of the success of human adaptation to local environments and potential for population growth. High productivity of hunting and fishing may have high economic returns but may severely disrupt and destroy particular species and ecosystems. In contrast, low productivity may place few strains on faunal resources but acute ones on the human society involved.

Feedback from hunting and fishing productivity influences decisions on what animals should be sought. Manatee (Trichechus manatus), a large aquatic 
mammal, is one of the most desired meats, but is also one of the most difficult animals to hunt, being a very wary animal with extremely acute hearing. Therefore, only limited pressure is placed on these animals because of low return for time invested, even though meat preference and size of yield (sometimes over $500 \mathrm{lb})$ are attractive.

\section{Meat Yields of Biotopes}

"It looks to me like the sea is much richer than the lagoon in every kind of food."

$$
\text { -A Tasbapauni turtleman }
$$

The Miskito recognize many biotopes, mostly in terms of structural composition. They perceive the relation of specific animal species to particular biotopes and direct their meat-getting activities accordingly. Certain biotopes were more productive than others because they contained the desired animal species and were accessible, and because hunting and fishing were dependable. However, the Miskito have adapted to a small range of animals which inhabit several selected biotopes, not to the biotopes themselves. ${ }^{9}$

Within the shallow offshore water area, shoals, turtle banks (turtle grass-covered subsurface feeding grounds), and "mudset" (close to shore mud-bottomed zone) areas were the most productive, yielding $79 \%$ of the total annual catch. On land, palm swamps, old and new swiddens, and secondary forests had the highest return of meat. In the lagoon-river resource sphere, the shallow water shrimp banks, grass flats, and shallow water borders provided most of the meat. In all, approximately $87 \%$ of the meat was obtained from the water and $13 \%$ from land.

\section{Distances in Hunting and Fishing}

In compiling data on hunting and fishing yields, round-trip distances to the "kill site" were noted. Meat yields relative to distance are not on an even ascending or descending gradient. Instead the pattern is one of alternating highs and lows corresponding to the location of productive and unproductive biotopes. Marine and terrestrial faunas are not distributed evenly throughout an area. Rather, they commonly occur in restricted areas, under specific ecological conditions, and at certain times of the year (Nietschmann, 1970a).

The long distances journeyed for hunting and fishing by the Miskito of Tasbapauni are similar to the situations in other coastal villages. The turtlemen in the Sandy Bay communities of the northern coast go 50 to 60 miles round trip to turtling grounds and 10 to 15 miles up the Ulang River for hunting. Just

9 See Flannery (1968: 67) for further discussion of this idea. 
north of Tasbapauni in the villages of Rio Grande Bar and Little Sandy Bay, turtlemen travel 12 to 15 miles out to Man O' War Cays and hunters go 10 to 20 miles up the Río Grande. It is not uncommon for some coastal Miskito to have to go one and two days by dugout to upriver hunting areas. Miskito hunting and fishing behavior is fixed on specific animals in specific biotopes even though the Miskito may have to go long distances to do so. High dependability in obtaining a particular desired meat appears to be more important than high productivity of just any meat.

\section{Time Inputs}

The expenditure of time involved in hunting and fishing offers a convenient means of comparing the productivity of these two different activities. However, measuring time inputs proved to be extremely difficult. Time inputs and meat returns varied tremendously from individual to individual and from season to season, much more so than in agriculture.

In Table $\mathrm{V}$ inputs of time and meat yield outputs are presented for a hunter and a turtleman. Both of these men obtained approximately the same amount of meat during the 12-month study period. Each split the total meat take with a partner. The turtleman made fewer trips, but each of longer duration, than did the hunter. Both spent a great deal of time in travel: the

Table V. Time and Yield Data for Hunting and Turtle Fishing, Tasbapauni, October 1968 Through September 1969 a

\begin{tabular}{|c|c|c|c|c|}
\hline & $\begin{array}{l}\text { Pounds of } \\
\text { meat (share) }\end{array}$ & $\begin{array}{l}\text { Total } \\
\text { hours }\end{array}$ & $\begin{array}{l}\text { Hours } \\
\text { traveling }\end{array}$ & $\begin{array}{l}\text { Hours hunting } \\
\text { and fishing }\end{array}$ \\
\hline Hunter & 875 & 533 & 305 & 228 \\
\hline \multirow[t]{2}{*}{ Turtleman } & 812 & 455 & 241 & 214 \\
\hline & Pounds of meat:hour & Calories & Protein $(\mathrm{g})$ & Fat (g) \\
\hline Hunter & $1.64: 1$ & 677,044 & 73,317 & 41,496 \\
\hline \multirow[t]{2}{*}{ Turtleman } & $1.78: 1$ & 437,500 & 78,750 & 7,875 \\
\hline & Calories per hour & Grams of protein per hour & \multicolumn{2}{|c|}{ Grams of fat per hour } \\
\hline \multirow{3}{*}{$\begin{array}{l}\text { Hunter } \\
\text { Turtleman }\end{array}$} & 1270 & 138 & \multirow{2}{*}{\multicolumn{2}{|c|}{$\begin{array}{l}78 \\
17\end{array}$}} \\
\hline & 962 & 173 & & \\
\hline & Number of trips & $\begin{array}{c}\text { Number of successful } \\
\text { trips }\end{array}$ & \multicolumn{2}{|c|}{$\begin{array}{c}\text { Percentage of successful } \\
\text { trips }\end{array}$} \\
\hline $\begin{array}{l}\text { Hunter } \\
\text { Turtleman }\end{array}$ & $\begin{array}{l}26 \\
15\end{array}$ & $\begin{array}{l}14 \\
11\end{array}$ & \multicolumn{2}{|c|}{$\begin{array}{l}54 \\
73\end{array}$} \\
\hline
\end{tabular}

aComposition of turtle, deer, and white-lipped peccary meats was adjusted from Wu Leung (1961) to allow for Miskito consumption of "mixed meat" and fat. 
turtleman $241 \mathrm{hr}(53 \%)$ and the hunter $305 \mathrm{hr}(57 \%)$. The turtleman had a slightly higher return of meat for every hour invested $(1.78 \mathrm{lb}$ versus $1.64 \mathrm{lb})$ and considerably more grams of protein per hour (173 versus 138$)$ than did the hunter. On the other hand, hunting provided more calories per hour of time (1270 versus 962) than did turtling, due in large part to the high fat composition of white-lipped peccary. The Miskito's liking for fatty meat prompts hunting efforts toward white-lipped peccary. This animal made up $70 \%$ of the total meat yield for the hunter in this example, while whitetail deer provided most of the balance.

The most significant difference, and one of the major reasons there are more turtlemen than hunters in the village, is that the percentage of successful trips was much higher for the turtlemen ( $73 \%$ versus $54 \%$ ). Thus the turtlemen went out from the village fewer times and had a greater chance of getting meat than did the hunters. In short, turtle fishing reduces the subsistence risk of meat-getting. It is not how much time or effort is expended to get a particular species that is important to a Miskito, but the degree of certainty in getting it.

In addition to the low subsistence risk of turtle fishing compared with hunting, another reason for the dominance of turtling is the high protein return. Hunting is generally more productive in calorie returns than turtling, but agricultural calorie productivity is so overshadowing that their margin of difference is almost meaningless. On the other hand, the protein return (grams of protein yield per hour) for turtling is $20 \%$ higher than for hunting. Added to this the fact that the protein return is also almost $20 \%$ more dependable in turtling than hunting, it is evident that Miskito meat-getting strategy has considerably reduced subsistence risk and increased protein productivity by concentrating on turtle fishing. Therefore, even though the Tasbapauni Miskito are on the edge of a vast tropical forest environment, more than $65 \%$ of the active adult men concentrate their meat-getting efforts only on turtling.

\section{The Impact of Economic Change}

Economic patterns in Miskito villages are changing from subsistence-based generalized reciprocity to monetary exchange. Economic systems are becoming more open, more linked to local, regional, national, and even international markets. Intensified exploitation of ecosystem resources has followed the Miskito's deepening engagement with a market economy, encouraging them to fulfill cultural needs by the sale of forest and sea products.

Much of the Tasbapauni Miskito's involvement with a market economy revolves around items taken by hunting and fishing: various meats, green turtle calipee, ${ }^{10}$ animal skins, hawksbill shell, and shrimp. Surplus from hunting and

10 Calipee is the cartilaginous amber and dark grey colored substance obtained from inside the lower and upper shells of the green turtle. It is used as the basis for green turtle soup in the United States and England. 
fishing for potential sale is created in three ways: (1) intensifying pressure on fauna to increase returns, (2) withholding portions of meat from socially regulated distribution networks, and (3) decreasing amount of meat consumed by the hunter's or turtleman's family.

Within the village a small money-based economy operates alongside the reciprocal exchange system. Economic transactions among many villagers are mainly over meat. In theory once principal social obligations for the distribution of meat are met, a hunter or turtleman is free to sell any remaining meat. Just as social relationships should be honored through the giving of first-quality meats, so too should sales be made. One cannot sell simply any meat, no matter how meat-starved the people may be. Tapir, shrimp, collared peccary, and some monkeys, for example, are not readily sold since they are considered less than "real meat." Increasingly tied into a market economy, Miskito hunters and fishermen are focusing on animals with a high market potential in the village. After discussing this idea with a hunter-turtleman he replied with customary Miskito wit and directness: "If you bring two deer in, you are the man. People say they don't have any money, but when meat comes, cordobas come."1 1

The Miskito have sold or traded wild animal products to foreigners since the early seventeenth century, but subsistence considerations usually have predominated in hunting and fishing focus and intensity. Trade contacts were intermittent and frequently lapsed for long periods. Therefore, market exploitation pressure was discontinuous and conditioned by obligations in agriculture and meat-getting for the table.

Market opportunities for faunal resources are expanding, especially during the last few years, and are becoming important determinants of hunting and fishing selection and season. Coincident with rising prices for animal products has been a steady increase in the exploitation of market animals. The Miskito are beginning to concentrate on market opportunities in their choice of game animals. Or, as one Miskito put it: "People are following the money just like ants follow the sugar."

Exploitation pressure on hawksbill, for example, has been intensified. In the first six months of 1971 , approximately 107 hawksbill were taken by Tasbapauni turtlemen, an increase of $400 \%$ over the 27 hawksbill taken during the same period in 1969. The meat is seldom eaten by the Miskito, and in 1969 a hawksbill was worth less than a green turtle, bringing perhaps $\$ 5.00$ for three or four pounds of shell while a green turtle could furnish $\$ 7.00$ to $\$ 10.00$ through the sale of meat in the village and calipee to Bluefields buyers. The dugout canoes used by the Miskito to harpoon turtles have a limited load capacity of three to four turtles, and until recently the Miskito preferred to bring in the

11 One cordoba is equal to $\$ 0.14$ US (seven córdobas to the dollar). 
more desirable green turtles, not hawksbill. Now this has changed. Hawksbill shell can be sold for $\$ 2.40$ a pound in Tasbapauni or $\$ 3.50$ a pound in Bluefields, thus earning the turtlemen $\$ 8.00$ to $\$ 13.00$ for most hawksbill (Fig. 5).

While he was scraping a few barnacles from some hawksbill shell, an inquisitive and perceptive Miskito asked me: "What do they make from the hawksbill shell?" "Oh, combs, bracelets, earrings-things like that," I replied. "So, that's why the hawksbill is in trouble. Because of these things, he has to be careful."

Commercial sale of animal products is not only inducing the Miskito to seek animals according to world market demands, it is prompting them to

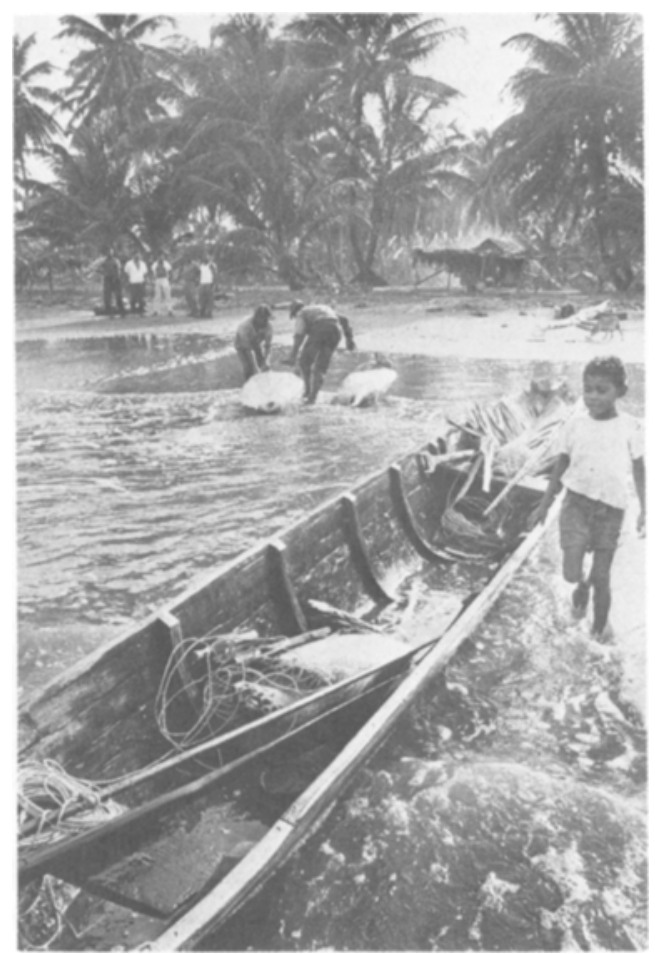

Fig. 5. Unloading turtles on the Tasbapauni beach in the late afternoon. Two green turtles /Chelonia mydas mydas) are being pulled up out of the water while a hawksbill turtle (Eretomochelys imbricata imbricata) remains in the dugout canoe. Because of their high value, hawksbill turtles are eagerly sought. Various turtle fishing gear can be seen: palm wood turtle harpoons, 30-fathom lines, paddles, and a bailing calabash. 
Table VI. Tasbapauni Green Turtle Catches and Sales for the First Half of 1969 and 1971 (Recorded and Estimated)

\begin{tabular}{lccr}
\hline & Butchered in village & Sold outside of village & Total \\
\hline 1969 (Jan.-June) & 437 & $47^{a}$ & 484 \\
1971 (Jan.-June) & 374 & $731^{b}$ & 1105 \\
\hline
\end{tabular}

${ }_{b}^{a}$ Sold in Bluefields.

$b$ Sold primarily to turtle companies.

exploit green turtles more intensively. Starting in late 1969, a foreign-owned turtle meat packing company began operations in Bluefields and in 1970 another turtle company opened in Puerto Cabezas. Both of these companies send their boats to the coastal villages and cays to buy turtles at $\$ 10.00$ for every one over $125 \mathrm{lb}$. Previously, the Miskito had to bear the costs of transporting the turtles to Bluefields and Puerto Cabezas and received less money from local butchers.

With an assured market and high prices from the turtle companies, the Tasbapauni Miskito began to concentrate even more sharply on green turtles. Exploitation rates in Tasbapauni for the first six months of 1971 were up $228 \%$ over a comparable period in 1969.12 Market sales outside of the village have increased $1500 \%$ while consumption of turtles in the village declined by $14 \%$ (Table VI). The Tasbapauni Miskito are catching and selling more green turtles but eating less. During the first half of 1971 alone, the Tasbapauni turtlemen sold almost as many turtles as had supplied most of the village's meat for one year during our earlier field work. "If the company wouldn't buy them, that amount of turtle wouldn't be caught," observed a Miskito.

In addition, external market considerations are now heavily influencing the regulation of hunting and fishing activities. Hunting and fishing were previously regulated by the seasonal availability of wild fauna and by the need to schedule work efforts in other phases of subsistence activities. Thus, hunting and fishing pursuits took place within an interface zone defined by ecological and subsistence system regulation. With the restructuring of the Miskito's economic system, another factor is coming in to play: market economy-directed wants and means. Therefore, hunting and fishing efforts are beginning to extend beyond the peak seasonal availability of desired species and they are also coming into conflict with the scheduling of other procurement systems, particularly agriculture. In Tasbapauni, for example, turtlemen are staying out longer and

12 Since 1965 the Nicaraguan Government has imposed a two-month prohibition against taking green turtles off the east coast (May 15-July 15). Most of the turtles included in the six-month figures were taken before mid-May, although some turtles caught before the deadline were legally sold to the companies during the prohibition period. 
going farther in their search for green turtles and devoting less time and less area to agriculture than they did two years ago.

Miskito hunting and fishing efforts are rapidly shifting from subsistence-directed to market-controlled. This is one of the major changes in hunting and fishing motivation that we noticed in 1971. The exploitation of faunal resources at present is highly concentrated on specific food animals to satisfy subsistence meat requirements and village market sale, as well as broadly ranging to include other species sought for foreign markets. Thus, populations of green turtles, white-lipped peccary, and whitetail deer are receiving additional pressure from human populations because of their taste preference and marketable potential, while several other species are being subjected to intensifying exploitation. Populations of hawksbill turtles, crocodiles, caimans, fresh-water otters, jaguars, ocelots, margays, and lobster are all severely depleted or almost exterminated over much of eastern Nicaragua (Nietschmann, 1971).

The Tasbapauni area still has quantities of diverse wild fauna because of the extensiveness of the land and water environments and because of the villager's concentration on sea turtles. Distance barriers and refuge pockets will soon be broken down. in the Miskito's search for meat and money animals.

Developing markets for new and different wild animal products influence the Miskito's perception of just what are fish and game animals. At present, many Miskito are beginning to operate under the assumption which might be characterized: "If they'll buy it, we'll get it." Changing Miskito attitudes and the future direction of faunal exploitation was exemplified by a remark made by a Miskito about the recent market for pieces of throat and shoulder skin from the loggerhead sea turtle (Caretta caretta): "We never bothered with the loggerhead, since we don't eat the meat. But now those turtles have to watch out; they buy the skin."

\section{POPULATION, CARRYING CAPACITY, AND TURTLES}

The amount of meat from fish and game animals which the Tasbapauni area can yield is limited. Increased population and market involvement will strain the ability of the area to supply meat in quantity concomitant with Miskito desires and needs. Either derived wants or exploitation pressure will have to be reduced or carrying capacity ${ }^{13}$ levels will soon be exceeded.

If a group hunts or fishes for subsistence only, that is, for satisfaction of

13 Human carrying : capacity refers to the theoretical maximum population total at a subsistence level which can be supported with a given technology without environmental degradation. The concept implies a measurable equilibrium relationship between population, resources, and environmental quality. Application of carrying capacity formulas to problems of human ecology has been hampered by conceptual as well as data acquisition problems. 
animal protein needs (cultural as well as biological), then their exploitation pressure is limited by some factor of their total population size. If the subsistence system is opened to permit circulation of meat outside the social network for monetary return, then the regulation of hunting and fishing activities becomes market-dependent rather than population-dependent. Increased market-directed killing of fish and game animals has a similar effect on an ecosystem as if the human population were suddenly enlarged. Therefore, the area's ability to support a population may be decreased (reduced carrying capacity) because of "cultural mimicry" of expanded subsistence population.

Attempts by geographers and anthropologists to measure carrying capacity have been based primarily on how much land is needed to supply a given amount of vegetable foodstuffs for a given amount of people. However, consideration of carrying capacity should include all sources of food which are normally consumed by the group in question. If any environmental resources are depleted in such a manner as to be unable to supply traditional levels of dietary intake, or if those resources fall below a critical threshold level, then the carrying capacity has been exceeded. Meat from hunting or fishing may make up only 5 to $10 \%$ of the diet, but it may be one of the most critical factors in the group's ecological adjustment to the area and therefore has to be considered when assessing carrying capacity. Carrying capacity estimates in the future will be much more remunerative if based on protein as well as caloric availability and intake.

Population growth is one of the principal agents which changes carrying capacity levels. Based on an estimated annual growth of $3.3 \%$, the current Nicaraguan Miskito population of 35,000 will increase to 48,000 in 10 years and to 66,500 in 20 years (Nietschmann, 1970b: 66,338). The Miskito are having to support their growing population with local resources. Increasing pressure will be placed on fish and game populations to meet nutritional demands for animal protein. Maintaining the present quality of Tasbapauni Miskito dietary patterns in the future will be as closely correlated to what happens to green turtle, white-lipped peccary, and whitetail deer populations as it will to increasing the area under cultivation to meet population growth.

The Miskito of Tasbapauni and of coastal eastern Nicaragua in general have adapted much of their meat-getting strategies and behavior to green turtles, which, in the case of Tasbapauni, supplied $70 \%$ of their annual meat intake by weight. Therefore, what is happening and what will happen to green turtle populations has a great deal to do with the future adaptive patterns of the Miskito.

The green turtle is an endangered species. Long-term exploitation of the only major nesting beach left in the Western Caribbean at Tortuguero, Costa Rica, and the effects of years of commercial and subsistence turtling of resident Nicaraguan turtle herds by Cayman Islanders and Miskito Indians have reduced their once vast numbers to scattered refuge populations. 
Recent turtle catches from the waters off eastern Nicaragua have risen steadily since the two turtle meat packing companies began buying from the Miskito in late 1969 and early 1970 (Table VII). Even though the Nicaraguan green turtle population is probably the largest remnant in the Western Caribbean, there can be no doubt that the depleted herds are in serious trouble and will be unable to withstand the current rate of market exploitation.

Thus, prompted by population increase and market involvement, the coastal Miskito are becoming increasingly specialized and dependent on the green turtle, now a threatened species. In so doing the Miskito are exceeding the coastal environment's carrying capacity by aiding in the degradation of the turtle herds. In the past, under low population numbers living at subsistence, Miskito hunting and fishing strategy was adapted to high assurance, high returns of specific species, particularly the green turtle. However, coastal Miskito hunting and fishing patterns are becoming maladaptive because of market-dependent intensification of faunal exploitation and resultant faunal decline.

\section{TRENDS AND PROSPECTS}

Large-scale changes in man-animal relationships were observed during our 1971 field research.14 Certain developing pathological trends are becoming evident in coastal Miskito society and culture which are being generated to a large degree by accelerated market hunting and fishing. Subsistence agriculture is being disrupted and reduced through a shift of labor to turtling for market. In order to create surplus to sell-either in the village or to turtle companies-many kinship obligations are not being honored with a gift of meat, thereby cutting

14 The reasons and consequences of social, cultural, and environmental change for the Miskito are discussed more fully in a book to be published in 1972 (Nietschmann, B., Between Land and Water, Seminar Press, New York, in press).

Table VII. Estimated Number of Green Turtles Taken Before and After Turtle Companies Began to Purchase from the Miskito ${ }^{a}$

\begin{tabular}{lrc}
\hline & Turtles taken by Miskito $^{b}$ & Turtles sold to companies \\
\hline 1968 & 4,000 & - \\
1969 & $5,000-6,000$ & 1000 \\
1970 & $8,000-10,000$ & 5000 \\
1971 (7 months) & 6,000 & 4000
\end{tabular}

$a$ Based on turtle company records - "Frescamar" in Bluefields and "Tortugas S.A." in Puerto Cabezas - and reconnaissances of turtle villages.

$b$ Most of the turtles taken by the Miskito and not sold to the turtle companies are eaten in the villages. 
off some families from the protein distribution system. Protein intakes are declining as meat is sold outside of the village system and carbohydrates are returned in their place through purchase.

Many coastal Miskito villages are tending to become overly specialized in hunting and fishing exploitation, less diversified in subsistence procurement, and economically dependent on declining faunal resources. Short-term economic returns will be gained at the expense of social and ecological disruptions.

In the past, highly focused Miskito hunting and fishing efforts were selected to guarantee substantial quantities of meat for subsistence consumption and satisfaction of social responsibilities. Meat procurement was largely for subsistence provisioning and limited by population. On the other hand, the degree of present intensified faunal exploitation is largely caused by population and market. Meat procurement is increasingly for market and provisioning is the by-product.

Some Miskito are aware of the ecological blind alley they are entering: becoming dependent on delining resources. But they have few alternatives which will provide monetary return. Conflicts between stipulated social behavior and contradictory market behavior with meat are becoming frequent. But the Miskito can speak for themselves, and as one "older head" pointed out:

"In the beginning there was no selling business here. When it came, the Indians grumbled. They said it was spoiling the place. Now that they're playing with the scale, everyone is selling. The Indian doesn't like that. I'm not going to give them meat; let them cook the money."

\section{REFERENCES}

Adams, R. N. (1956). Cultural components of Central America. American Anthropologist 58: 881-907.

Bennett, C. F. (1962). The Bayano Cuna Indians, Panama: An ecological study of livelihood and diet. Annals of the Association of American Geographers 52: 32-50.

Bennet, C. F. (1967). A review of ecological research in Middle America. Latin American Research Review 2(3): 3-27.

Bennet, C. F. (1970). Animal geography in Latin America. In National Conference of Latin Americanist Geographers, Muncie, Indiania, 1970 (preliminary edition), pp. 19-34.

Carneiro, R. L. (1960). Slash-and-burn agriculture: A closer look at its implications for settlement patterns. In Wallace, F. C. (ed.), Men and Cultures: Selected Papers of the Fifth International Congress of Anthropological and Ethnological Sciences, University of Pennsylvania Press, Philadelphia, pp. 229-234.

Carneiro, R. L. (1961). Slash-and-burn cultivation among the Kuikuru and its implications for cultural development in the Amazon Basin. In Wilbert, J. (ed.), The Evolution of Horticultural Systems in Native South American, Causes and Consequences: $A$ Symposium, Sociedad de Ciencias Naturales La Salle, Caracas, pp. 47-67.

Carneiro, R. L. (1964). Shifting cultivation among the Amahuaca of Eastern Peru. Völkerkundliche Abhandlungen 1: 9-18.

Carneiro, R. L. (1970). The transition from hunting to horticulture in the Amazon Basin. Proceedings VIIIth Congress of Anthropological and Ethnological Sciences, Tokyo and Kyoto, 1968, Vol. 3, Ethnology and Archáeology, Science Council of Japan, Tokyo, pp. 244-248. 
Carr, A. (1967). So Excellent a Fishe: A Natural History of Sea Turtles. The Natural History Press, New York.

Denevan, W. M. (1966). A cultural-ecological view of former aborginal settlement in the Amazon Basin. The Professional Geographer 18: 346-351.

Flannery, K. V. (1968). Archaeological systems theory and early Mesoamerica. Anthropological Archaeology in the Americas, The Anthropological Society of Washington, Washington, D.C., pp. 67-87.

Kirchhoff, P. (1948). The Caribbean lowland tribes: the Miskito, Sumus, Paya and Jicaque. In Steward, J. (ed.), Handbook of South American Indians, U.S. Bureau of American Ethnology Bulletin No. 143, Vol. 4, pp. 219-229.

Lathrap, D. W. (1968). The "hunting" economies of the tropical forest zone of South America: An attempt at historical perspective. In Lee, R. B., and Devore, I. (eds.), Man the Hunter, Aldine, Chicago, pp. 23-29.

Nietschmann, B. (1969). The distribution of Miskito, Sumu, and Rama Indians, Eastern Nicaragua. Bulletin of the International Committee on Urgent Anthropological and Ethnological Research, International Union of Anthropological and Ethnological Sciences (Vienna) 11: 91-102.

Nietschmann, B. (1970a). The Measurement of subsistence. In National Conference of Latin Americanist Geographers, Muncie, Indiana, 1970 (preliminary edition), pp. 221-233.

Nietschmann, B. (1970b). Between land and water: The subsistence ecology of the Miskito Indians, Eastern Nicaragua. Unpublished doctoral dissertation in geography. University of Wisconsin.

Nietschmann, B. (1971). Destrucción de la fauna de la costa Atlántica. La Prensa, Managua, Nicaragua, September 5, 1971.

Nietschmann, B. (in press). Between Land and Water. Seminar Press, New York.

Parsons, J. J. (1962). The Green Turtle and Man. University of Florida Press, Gainesville.

Wu Leung, Woot-Tsuen (1961). Food Composition Table for Use in Latin America. National Institutes of Health, Bethesda, Maryland. 